\title{
Deaths from injury in children and employment status in family: analysis of trends in class specific death rates
}

\author{
Phil Edwards, Judith Green, Ian Roberts, Suzanne Lutchmun
}

\begin{abstract}
Objective To examine socioeconomic inequalities in rates of death from injury in children in England and Wales.

Design Analysis of rates of death from injury in children by the eight class version of the National Statistics Socio-Economic Classification (NS-SEC) and by the registrar general's social classification.

Setting England and Wales during periods of four years around the 1981, 1991, and 2001 censuses.

Subjects Children aged 0-15 years.

Main outcome measures Death rates from injury and poisoning.

Results Rates of death from injury in children fell from 11.1 deaths (95\% confidence interval 10.8 to 11.5 deaths) per 100000 children per year around the 1981 census to 4.0 deaths (3.8 to 4.2 deaths) per 100000 children per year around the 2001 census. Socioeconomic inequalities remain: the death rate from all external causes for children of parents classified as never having worked or as long term unemployed (NS-SEC 8) was 13.1 (10.3 to 16.5) times that for children in NS-SEC 1(higher managerial/professional occupations). For deaths as pedestrians the rate in NS-SEC 8 was 20.6 (10.6 to 39.9) times higher than in NS-SEC 1; for deaths as cyclists it was 27.5 (6.4 to 118.2) times higher; for deaths due to fires it was 37.7 (11.6 to 121.9) times higher; and for deaths of undetermined intent it was 32.6 (15.8 to 67.2) times higher.

Conclusions Overall rates of death from injury and poisoning in children have fallen in England and Wales over the past 20 years, except for rates in children in families in which no adult is in paid employment. Serious inequalities in injury death rates remain, particularly for pedestrians, cyclists, house fires, and deaths of undetermined intent.
\end{abstract}

\section{Introduction}

Ten years ago, research identified steep and widening social class gradients in mortality from injury among children aged $<15$ years in England and Wales. ${ }^{12}$ The death rate from injury and poisoning for children in the lowest social class was five times greater than that for children in the highest social class. Inequalities were found to be greatest for injuries related to fires and those incurred as pedestrians, where the mortality rate ratios between lowest and highest social classes were 15 times and 5 times greater respectively. We examined whether these gradients persist at the start of the 21st century.

\section{Methods}

We obtained a data file from the Office for National Statistics containing the anonymised records of all deaths of children (0-15 years) from injury in England and Wales during periods of four years around the 1981, 1991, and 2001 censuses. For the period around the 1981 census, we used deaths in 1979, 1980, 1982, and 1983 because the records for 1981 were unreliable. For the periods around the 1991 and 2001 censuses we used deaths during 1989-92 and 2001-3, respectively. We used the three year period 2001-3 because of changes introduced in 2001 to the coding of underlying cause of death and social class and because the records for deaths in 2004 were not available.

Each record included the year of death, the underlying cause of death, and the parents' socioeconomic class. Cause of death was coded according to the chapter on external causes of morbidity and mortality in the international classification of diseases (ICD) (using the ninth revision for deaths before 2001 and the 10th revision for deaths from 2001 onwards). Socioeconomic class was coded according to the registrar general's social classification for deaths before 2001 and to the eight class version of the National Statistics Socio-Economic Classification (NS-SEC) for deaths from 2001 onwards. ${ }^{3}$ For our analysis, we based the child's classification on the father's socioeconomic class or the mother's socioeconomic class if the father's was missing.

We calculated death rates from injury for all causes of injury and poisoning combined, using population data from each census. For the most recent period we also calculated death rates for the leading causes of death. To increase the precision of our estimates, we combined the deaths during the years in each of the three periods. We used the Poisson distribution to estimate death rates with $95 \%$ confidence intervals.

\section{Results}

The average annual death rate from injury around the 2001 census was 4.0 per 100000 children aged $0-15$ years $(95 \%$ confidence interval 3.8 to 4.2 deaths), compared with 8.1 per 100000 children ( 7.8 to 8.4 deaths) around the 1991 census and 11.1 per 100000 children (10.8 to 11.5 deaths) around the 1981 census.

Table 1 shows the numbers of deaths from injury and poisoning and rates per year per 100000 children aged 0-15 years by the eight class NS-SEC for the period 2001-3. The death rate for children of parents classified as never having worked or as long term unemployed (NS-SEC class 8) was 13.1 (10.3 to

A table of the results stratified by age group can be found on bmj.com. 
Table 1 Deaths from injury and poisoning and rates per year per 100000 children aged 0-15 years by eight class NS-SEC, 2001-3

\begin{tabular}{lcc} 
NS-SEC & $\begin{array}{c}\text { Deaths } \\
\mathbf{2 0 0 1 - 3 \dagger}\end{array}$ & $\begin{array}{c}\text { Rate } \mathbf{( 9 5 \%} \text { CI) per year } \\
\text { per } \mathbf{1 0 0} \mathbf{0 0 0} \text { children }\end{array}$ \\
\hline 1: Higher managerial/professional occupations & 85 & $1.9(1.6$ to 2.4$)$ \\
\hline 2: Lower managerial/professional occupations & 111 & $1.6(1.3$ to 1.9$)$ \\
\hline 3: Intermediate occupations & 59 & $2.9(2.2$ to 3.7) \\
\hline 4: Small employers/own account workers & 105 & $2.9(2.4$ to 3.5) \\
\hline 5: Lower supervisory/technical occupations & 91 & $2.7(2.2$ to 3.3) \\
\hline 6: Semi-routine occupations & 148 & $4.0(3.4$ to 4.7) \\
\hline 7: Routine occupations & 180 & $5.0(4.3$ to 5.8) \\
\hline 8: Never worked/long term unemployed & 383 & $25.4(22.9$ to 28.1) \\
\hline Total & 1162 & $4.0(3.8$ to 4.2)
\end{tabular}

NS-SEC=National Statistics Socio-Economic Classification.

†Excludes one child for whom NS-SEC was missing

16.5) times that for children of parents in higher managerial and professional occupations (NS-SEC class 1). For children of parents in routine occupations (NS-SEC class 7) the death rate was 2.6 (2.0 to 3.4) times higher than in NS-SEC class 1. The figure shows the average annual death rates by NS-SEC or by the registrar general's social classification for each of the three time periods.

Table 2 shows the causes of death due to injury and poisoning around the 2001 census. The seven leading causes accounted for over $80 \%$ of deaths from injury. Table 3 shows the annual death rates per 100000 children aged $0-15$ years by NS-SEC for the leading causes. Compared with children of parents in class NS-SEC 1, the death rate in children of parents in class NS-SEC 8 was higher for each of these causes: 20.6 (10.6 to 39.9) times higher for deaths as pedestrians, 5.5 (3.1 to 9.6) times higher for deaths as car occupants, 27.5 (6.4 to 118.2) times higher for deaths as cyclists, 16.7 (8.3 to 34.0) times higher for deaths due to other accidental threats to breathing, 37.7 (11.6 to 121.9) times higher for deaths due to exposure to smoke, fire, and flames, and 32.6 (15.8 to 67.2) times higher for deaths of undetermined intent (all ratios based on the estimated death rates before rounding).

\section{Discussion}

Death rates from injury and poisoning in children in England and Wales have fallen over the past 20 years. Given the relatively low absolute numbers of deaths, it is surprising that a socioeco-
Table 2 Deaths from injury and poisoning among children aged 0-15 years by external cause for the period 2001-3

\begin{tabular}{|c|c|c|}
\hline Cause & ICD-10 codes & Deaths $(\%)$ \\
\hline Pedestrian injured in transport incident & V01-V09 & $205(18)$ \\
\hline Events of undetermined intent & Y10-Y34 & $202(17)$ \\
\hline Other accidental threats to breathing & W75-W84 & $173(15)$ \\
\hline Car occupant injured in transport accident & V40-V49 & $142(12)$ \\
\hline Exposure to smoke, fire, and flames & X00-X09 & $92(8)$ \\
\hline Accidental drowning and submersion & W65-W74 & $77(7)$ \\
\hline Pedal cyclist injured in transport accident & V10-V19 & $56(5)$ \\
\hline Other and unspecified transport accidents & V20-V39, V50-V99 & $49(4)$ \\
\hline Falls & W00-W19 & $40(3)$ \\
\hline $\begin{array}{l}\text { Exposure to animate and inanimate mechanical } \\
\text { forces; heat and hot substances; forces of } \\
\text { nature; electrical current } \\
\end{array}$ & $\begin{array}{l}\text { W20-W64, X10-X19, } \\
\text { X30-X39, W86-W87 }\end{array}$ & $33(3)$ \\
\hline Assault & X85-Y09 & $29(2)$ \\
\hline Intentional self harm & $\mathrm{X} 60-\mathrm{X} 84$ & $22(2)$ \\
\hline $\begin{array}{l}\text { Accidental exposure to other and unspecified } \\
\text { factors }\end{array}$ & $\mathrm{X} 58-\mathrm{X} 59$ & $17(1)$ \\
\hline $\begin{array}{l}\text { Complications of medical and surgical care; } \\
\text { sequelae of external causes of morbidity and } \\
\text { mortality }\end{array}$ & Y40-Y84, Y85-Y89 & $15(1)$ \\
\hline $\begin{array}{l}\text { Accidental poisoning with and exposure to } \\
\text { noxious substances }\end{array}$ & $\mathrm{X} 40-\mathrm{X} 49$ & $11(1)$ \\
\hline All causes & - & 1163 \\
\hline
\end{tabular}

nomic gradient remains for children with parents in paid employment: the rate of death in children with parents in routine occupations is over twice that in children with parents in higher managerial and professional occupations. More notably, the reductions in deaths from injury have not occurred in children in families with no adult in paid employment.

\section{Methodological issues}

The introduction of the National Statistics Socio-Economic Classification (NS-SEC) in 2001 precludes direct comparisons with previous analyses based on the registrar general's social classification. ${ }^{4}$ Comparisons of social gradients over time are therefore not possible, and we cannot assess whether socioeconomic inequalities are narrowing or widening. Recent data, however, show large differences in mortality between children whose parents are employed and those whose parents are not. The death rate for children of parents classified as never having worked or as long term unemployed was 13 times higher than that of children in the highest social group. According to the 2001 census, around 5\% of children in England and Wales

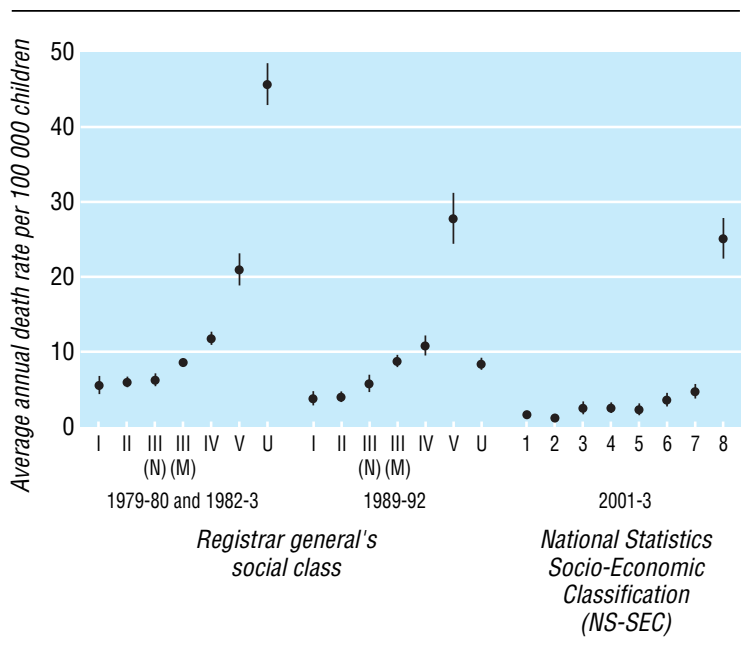

Average annual death rate from injury (with 95\% confidence intervals) per 100000 children aged 0-15 years by registrar general's social classification (I=professionals, II=managerial and technical, III(N)=skilled non-manual, III(M)=skilled manual, IV=partly skilled manual, V=unskilled manual, U=unoccupied) and by eight class NS-SEC (from 1 (higher managerial and professional occupations to 8 (never worked or long term unemployed), see table 1) 
Table 3 Rates of death from injury per year per 100000 children aged 0-15 years by eight class NS-SEC and external cause, 2001-3. Figures are number of deaths; rate (95\% confidence interval)

\begin{tabular}{|c|c|c|c|c|c|c|}
\hline NS-SEC & Pedestrians & Car occupant & Pedal cyclists & $\begin{array}{c}\text { Events of } \\
\text { undetermined intent }\end{array}$ & $\begin{array}{l}\text { Other accidental threats } \\
\text { to breathing }{ }^{\star}\end{array}$ & $\begin{array}{c}\text { Exposure to smoke, fire, } \\
\text { and flamest }\end{array}$ \\
\hline $\begin{array}{l}\text { 1: Higher managerial/ } \\
\text { professional occupations }\end{array}$ & $\begin{array}{c}10 \\
0.2(0.1 \text { to } 0.4)\end{array}$ & $\begin{array}{c}19 ; \\
0.4(0.3 \text { to } 0.7)\end{array}$ & $\begin{array}{c}2 ; \\
0.05(0.01 \text { to } 0.2)\end{array}$ & $\begin{array}{c}8 \\
0.2(0.1 \text { to } 0.4)\end{array}$ & $\begin{array}{c}9 ; \\
0.2(0.1 \text { to } 0.4)\end{array}$ & $\begin{array}{c}3 ; \\
0.1(0.01 \text { to } 0.2)\end{array}$ \\
\hline $\begin{array}{l}\text { 2: Lower managerial/ professional } \\
\text { occupations }\end{array}$ & $\begin{array}{c}15 \\
0.2(0.1 \text { to } 0.4)\end{array}$ & $\begin{array}{c}13 ; \\
0.2(0.1 \text { to } 0.3)\end{array}$ & $\begin{array}{c}6 ; \\
0.1(0.03 \text { to } 0.2)\end{array}$ & $\begin{array}{c}16 \\
0.2(0.1 \text { to } 0.4)\end{array}$ & $\begin{array}{c}21 ; \\
0.3(0.2 \text { to } 0.5)\end{array}$ & $\begin{array}{c}2 ; \\
0.03(0.004 \text { to } 0.1)\end{array}$ \\
\hline 3: Intermediate occupations & $\begin{array}{c}10 \\
0.5(0.2 \text { to } 0.9)\end{array}$ & $\begin{array}{c}8 ; \\
0.4(0.2 \text { to } 0.8)\end{array}$ & $\begin{array}{c}1 ; \\
0.05(0.001 \text { to } 0.3)\end{array}$ & $\begin{array}{c}11 ; \\
0.5(0.3 \text { to } 1.0)\end{array}$ & $\begin{array}{c}; \\
0.3(0.1 \text { to } 0.7)\end{array}$ & $\begin{array}{c}2 ; \\
0.1(0.01 \text { to } 0.4)\end{array}$ \\
\hline $\begin{array}{l}\text { 4: Small employers/own account } \\
\text { workers }\end{array}$ & $\begin{array}{c}19 ; \\
0.5(0.3 \text { to } 0.8)\end{array}$ & $\begin{array}{c}12 ; \\
0.3(0.2 \text { to } 0.6)\end{array}$ & $\begin{array}{c}6 ; \\
0.2(0.1 \text { to } 0.4) \\
\end{array}$ & 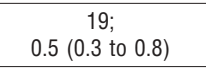 & $\begin{array}{c}13 ; \\
0.4(0.2 \text { to } 0.6)\end{array}$ & $\begin{array}{c}6 ; \\
0.2(0.1 \text { to } 0.4) \\
\end{array}$ \\
\hline $\begin{array}{l}\text { 5: Lower supervisory/ technical } \\
\text { occupations }\end{array}$ & $\begin{array}{c}16 ; \\
0.5(0.3 \text { to } 0.8)\end{array}$ & $\begin{array}{c}16 ; \\
0.5(0.3 \text { to } 0.8)\end{array}$ & $\begin{array}{c}2 ; \\
0.1(0.01 \text { to } 0.2)\end{array}$ & $\begin{array}{c}14 ; \\
0.4(0.2 \text { to } 0.7)\end{array}$ & $\begin{array}{c}15 \\
0.4(0.3 \text { to } 0.7)\end{array}$ & $\begin{array}{c}3 ; \\
0.1(0.02 \text { to } 0.3)\end{array}$ \\
\hline 6: Semi-routine occupations & $\begin{array}{c}23 ; \\
0.6(0.4 \text { to } 0.9)\end{array}$ & $\begin{array}{c}19 ; \\
0.5(0.3 \text { to } 0.8)\end{array}$ & $\begin{array}{c}11 \\
0.3(0.1 \text { to } 0.5)\end{array}$ & $\begin{array}{c}18 \\
0.5(0.3 \text { to } 0.8)\end{array}$ & $\begin{array}{c}26 ; \\
0.7(0.5 \text { to } 1.0)\end{array}$ & $\begin{array}{c}16 \\
0.4(0.2 \text { to } 0.7)\end{array}$ \\
\hline 7: Routine occupations & $\begin{array}{c}41 ; \\
1.1(0.8 \text { to } 1.6)\end{array}$ & $\begin{array}{c}19 ; \\
0.5(0.3 \text { to } 0.8)\end{array}$ & $\begin{array}{c}9 ; \\
0.3(0.1 \text { to } 0.5)\end{array}$ & $\begin{array}{c}26 ; \\
0.7(0.5 \text { to } 1.1)\end{array}$ & $\begin{array}{c}30 ; \\
0.8(0.6 \text { to } 1.2)\end{array}$ & 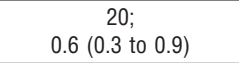 \\
\hline $\begin{array}{l}\text { 8: Never worked/long term } \\
\text { unemployed }\end{array}$ & $\begin{array}{c}71 ; \\
4.7 \text { (3.7 to } 5.9) \\
\end{array}$ & $\begin{array}{c}36 ; \\
2.4 \text { (1.7 to } 3.3) \\
\end{array}$ & $\begin{array}{c}19 ; \\
1.3(0.8 \text { to } 2.0) \\
\end{array}$ & $\begin{array}{c}90 ; \\
6.0(4.8 \text { to } 7.3) \\
\end{array}$ & $\begin{array}{c}52 ; \\
3.4(2.6 \text { to } 4.5) \\
\end{array}$ & $\begin{array}{c}39 ; \\
2.6 \text { (1.8 to } 3.5) \\
\end{array}$ \\
\hline Total & $\begin{array}{c}205 ; \\
0.7(0.6 \text { to } 0.8)\end{array}$ & $\begin{array}{c}142 ; \\
0.5(0.4 \text { to } 0.6)\end{array}$ & $\begin{array}{c}56 ; \\
0.2(0.1 \text { to } 0.3)\end{array}$ & $\begin{array}{c}202 ; \\
0.7(0.6 \text { to } 0.8)\end{array}$ & $\begin{array}{c}173 ; \\
0.6(0.5 \text { to } 0.7)\end{array}$ & $\begin{array}{c}91 ; \\
0.3(0.3 \text { to } 0.4)\end{array}$ \\
\hline
\end{tabular}

*Excludes accidental drowning and submersion.

†Excludes one child for whom NS-SEC was missing.

were classified as having parents in this group, but they accounted for 33\% of deaths in 2001-3.

Between the two earlier periods there was an unusually large decline in the annual death rate among the children of "unoccupied" parents (from 46 deaths per 100000 children in 1981 to 9 deaths per 100000 children in 1991). This may be due partly to a shift in the population distribution by social class from skilled and unskilled manual classes to unoccupied. Though absolute numbers of deaths fell between censuses by around one third in each social class, the proportion of the child population classified as from "unoccupied" families increased from $6 \%$ to $23 \%$.

\section{Strengths and weaknesses in relation to other studies}

Accidental deaths are subject to a coroner's inquest, which can delay registration and sometimes results in subsequent amendment to the underlying cause of death. ${ }^{5}$ The data we used were provided by the Office for National Statistics in 2005 and were therefore the most accurate and complete mortality data available at that time. In addition to calculating current child injury death rates by NS-SEC, we therefore also updated previous estimates of death rates for the periods around the 1981 and 1991 censuses. ${ }^{12}$ We found some differences between our new estimates and those made in the previous study, which are probably due to changes to the completeness and coding of mortality data over time.

To estimate child injury death rates for different socioeconomic groups we used mortality data classified according to social class at death and census data estimates of the child population at risk. The extent to which social class is assessed consistently within mortality and census data is therefore critical to the validity of our results as any such numerator-denominator bias could distort the social class gradients. Results from longitudinal studies that have linked census data with mortality data have found that numerator-denominator bias has little effect on social class mortality differentials. ${ }^{6}$ These analyses, however, were carried out by using the registrar general's social classification of deaths and similar studies using the National Statistics Socio-Economic Classification have yet to be completed. For this reason we cannot exclude the possibility of some numeratordenominator bias.

\section{Possible mechanisms and implications for policymakers}

We have identified a particularly high injury death rate for children whose parents are classified as never having worked or as long term unemployed. Our results show that children in these families face greater risks of dying in road traffic accidents and in fires and from undetermined causes than children in all other social groups. Despite the public health focus on injury being targeted at "particular areas of health inequality," their disadvantage remains. The reason for the overall fall in mortality from injury in children is probably due to the declining exposure of children to risk of injury, particularly as pedestrians. ${ }^{8}$ Explanations for the inequalities that persist between children from workless families and those in work are necessarily speculative but probably lie in different exposures to risk as there is no reliable evidence that differences in attitudes and knowledge can account for them. ${ }^{910}$ The higher risk of being killed as a pedestrian, compared with as a car occupant, certainly suggests greater exposure to risk of road injury. Their higher risks of dying in house fires may reflect the quality and type of housing, with the greatest risks for those in temporary and poor housing.

If all children in England and Wales had experienced the relatively low mortality seen among children in the most advantaged families, there would have been about 600 fewer deaths from injury and poisoning in 2001-3. Most of these avoidable deaths were of children from families with no adult in paid employment. At the beginning of the 21 st century there is evidence that the economic exclusion of the poorest families is reflected in significantly increased death rates from injury in childhood.

We thank the Office for National Statistics, in particular Mr Folkert van Galen, for providing the mortality and census data. We also thank Colin Cryer, whose comments helped to improve this paper.

Contributors: PE and IR designed the study, obtained the data, and conducted all analyses. All authors interpreted the data and wrote the paper. $\mathrm{PE}$ is guarantor.

Funding: This work was undertaken by the London School of Hygiene and Tropical Medicine, who received funding from the Department of Health. The views expressed in the publication are those of the authors and not necessarily those of the Department of Health.

Conflict of interest statement: None declared.

Ethical approval: Not required. 
Roberts I, Power C. Does the decline in child injury mortality vary by social class? A comparison of class specific mortality in 1981 and 1991. BMJ 1996;313:784-6.

2 Roberts I, DiGuiseppi C, Ward H. Childhood injuries: extent of the problem, epidemiological trends, and costs. Inj Prev 1998;4(suppl):S10-6.

\section{What is already known on this topic}

Steep and widening social class gradients in mortality from injury in children in England and Wales were identified 10 years ago

Inequalities were greatest for deaths of children in house fires and as pedestrians

\section{What this study adds}

Child injury deaths have fallen in most socioeconomic groups

Children in families with no adult in paid employment are a notable exception

Inequalities are still greatest for deaths of children in house fires and as pedestrians
3 National Statistics. The national statistics socio-economic classification. www.statistics.gov.uk/methods quality/ns sec/ (accessed 10 March 2006).

4 Rowan S. Implications of changes in the United Kingdom social and occupational classifications in 2001 on infant mortality statistics. Health Stat O 2003;17:33-41.

5 Devis T, Rooney C. The time taken to register a death. Popul Trends 1997;88:48-55.

6 Davey Smith G, Blane D, Bartley M. Explanations for socio-economic differentials in mortality. Eur J Public Health 1994;4:131-44.

Department of Health. Preventing accidental injury-priorities for action. Report to the chief medical officer. London: Stationery Office, 2002.

8 DiGuiseppi C, Roberts I, Li L. Influence of changing travel patterns of child death rates from injury: trend analysis. BMJ 1997;314:710-3.

9 Roberts H, Smith S, Bryce C. Children at risk? Safety as social value. Buckingham: Open University Press, 1995

10 Laflamme L, Diderichsen F. Social differences in traffic injury risks in childhood and youth-a literature review and research agenda. Inj Prev 2000;6:293-8.

(Accepted 24 March 2006)

doi $10.1136 / \mathrm{bmj} .38875 .757488 .4 \mathrm{~F}$

Department of Epidemiology and Population Health, London School of Hygiene and Tropical Medicine, London WC1E 7HT

Phil Edwards lecturer in statistics

Ian Roberts professor of epidemiology

Department of Public Health and Policy, London School of Hygiene and Tropical Medicine

Judith Green senior lecturer in sociology

Camden Primary Care Trust, St Pancras Hospital, London NW1 OPE

Suzanne Lutchmun injury prevention specialist

Correspondence to: P Edwards phil.edwards@LSHTM.ac.uk 